A partial version of this paper was presented at the Third Conference on Agriculture, Food and Human Values Society, Varieties of Sustainability, Reflecting on Ethics, Environment and Economic Equity, Asilomar Conference Center, Pacific Grove, California, May 10-12, 1991.

\section{Notes}

${ }^{1}$ All references to Frankenstein are to the Pyramid Book edition, 1957.

${ }^{2}$ M. C. Lugones and Elizabeth V. Spelman, "Have We Got a Theory for You! Feminist Theory, Cultural Imperialism and the Demand for 'the Women's Voice.' Women's Studies International Forum 6 (1983): 573-81.

${ }^{3}$ Aristotle, Politics, Bk ICh.8 1.16.

${ }^{4}$ René Descartes, "Discourse on Method," in Philosophical Works of Descartes, Vol I translated by E. S. Haldane and G. R. T. Ross (New York: Cambridge University Press, 1967) reprinted in Tom Regan and Peter Singer, eds. Animal Rights and Human Obligations (Englewood Cliffs, N. J.: Prentice-Hall, 1976) p.61.

${ }^{5}$ S. Griffin "Split Cultures," in Judith Plant, ed., Healing the Wounds (Philadelphia: New Society Publishers, 1989) pp. $11 \mathrm{ff}$.

6 Joel Feinberg, "The Rights of Animals and Unborn Generations, "reprinted in T. Mappes and J. Zembaty, Social Ethics, Morality and Social Policy (New York:McGraw Hill, 1987) p. 492.

${ }^{7}$ Immanuel Kant, "Duties to Animals and Spirits," in Lectures on Ethics, translated by Louis Infield ( New York : Harper and Row, 1963) reprinted in Animal Rights and Human Obligations, p. 122.

${ }^{8}$ Aldo Leopold, A Sand County Almanac (New York: Ballantine Books, 1970) p. 247.

9 Tom Regan, "The Nature and Possibility of an Environmental Ethic," All That Dwell Therein (Berkeley: University of California Press, 1982) p. 188. Also see, Holmes Rolston III, "Is There an Ecological Ethic?" Philosophy Gone Wild (Buffalo: Prometheus Books, 1986), p. 12 and Joanna Macy, "Awakening to the Ecological Self," in Healing the Wounds pp. 201-212.

${ }^{10}$ Iris Marion Young, Justice and the Politics of Difference (Princeton, N. J.: Princeton University Press, 1990) pp. 59 ff.

${ }^{11}$ Ibid. p. 146

\title{
Response: Dr. Frankenstein and Today's Professional Biotechnologist: A Failed Analogy?
}

\section{Laura Westra \\ Windsor University}

\section{Introduction}

I found this paper to be both instructive and problematic at the same time. Instructive, because although I had of course heard of Frankenstein, I had no direct acquaintance with the actual work, and this paper emphasized for me many issues relevant to my own research. The "problematic" aspect arose primarily because of the number of topics covered in the paper: questions concerning bioengineered species, the meaning of "stewardship" and of "sustainability" against a background of environmental abuse, finally, even the topic of "ecofeminism" introduced in the final portion of the paper. Clearly there are links among all of these topics: they are not unrelated. The question is how much of all of that can be usefully treated in one brief paper and in an even briefer response.

Thus, in the interest of both brevity and focus, I will focus, generally speaking, primarily on the analogy Dandekar and Zlotowski perceive between the original Frankenstein and his counterparts in bioengineering today. Starting with a sum-up of Dandekar and Zlotowski's analysis of the character of the fictional Frankenstein, I will then turn to a brief presentation of the reality of today's biotechnology, before assessing the analogies and disanalogies. From that standpoint, I

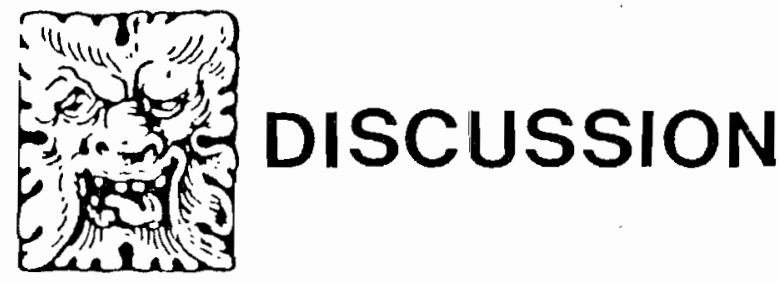


will then say a few words about the problems of "stewardship," "sustainability," and "ecofeminism" in my conclusion.

Throughout this response, I will not argue for or against Dandekar and Zlotowski's interpretation of the figure of Dr. Frankenstein. Time does not permit me to pursue an independent assessment, and I will simply accept their representation of the meaning and motivation of the character of Dr. Frankenstein, since this is a question of literary interpretation and scholarship, hence a secondary question within the present context.

\section{Dr. Frankenstein and}

\section{Nonhuman Bioengineered Species: Yesterday.}

The first thing to note is that Dr. Frankenstein emerges from the discussion of this paper as a typical upper class, well-educated male of his time: arrogant, unquestioning of traditional values, self-serving, sexist, hence, it goes without saying, speciesist. He is "the scientific expert who assumes a right to unmonitored experimentation" and who thinks "scientific knowledge is a self-legitimating good." He does not doubt either his capacity or his "right" to "create" a new life-form, yet his self-congratulation quickly turns to distaste: his "creation" horrifies and repels him. At the outset, "he presumes his quest good in itself"; hence his activity is

\section{unhindered by}

a) any moral reflection on probable consequences,

b) any respect for the sensibilities of the non-scientific public, and

c) any sense that the nonhuman itself might be owed respect.

Finally, Dandekar and Zlotowski further characterize Dr. Frankenstein as accepting both Christian and Biblical beliefs in regard to nonhuman life and the "cultural imperialism" that is based on human (specifically male) domination of the earth through "scientific progress" and capitalism.

In essence, Dandekar and Zlotowski see in Dr. Frankenstein the precursor of today's bioengineering specialists, such as those in plant pathology or the agricultural sciences. They also see in his attitude, from his initial elation at the successful completion of his professional efforts, to his belated "qualms" about divided loyalties, a replica of present day counterparts. But does the fictional character as it emerges, and his relation to the "creature" truly help to understand modern day biotechnologies and their creators? For an analogy to work, the entities deemed to be analogous must be alike in the most relevant respect. The first question to raise then, is, Is there a true analogy here? In order to answer this question, we must in turn carefully examine today's counterparts to Dr. Frankenstein, since only then will we be able to determine whether the analogy proposed in fact holds.

\section{Dr. Frankenstein and \\ Nonhuman Bioengineered Species: Today.}

Who are today's Dr. Frankensteins? For the most part, they are earnest young men and women, employed by large, multinational conglomerates, Monsanto, CibaGeigy, Upjohn, and even USDA. Bioengineering is a profession like many others, and the "products" of their professional activities are only "monstrous" from some specific perspectives, as we shall see. On the face of it, the final products consist of " new" engineered plants or domestic animals, but these often look as they always did, even though they are different in some significant way. A plant may have been bred with a virus so that the new creation is both "animal" and "vegetal," and it possesses traits the previous plant did not possess. These traits are desirable from the standpoint of economics and production: on the plus side, they increase yield, hence they promise to feed more people more efficiently; on the minus side, the new plant has now evolved into one with an inbred resistance to a specific herbicide. The result is that the bioengineered species, heralded as a step forward for environmental safety and a step away from chemicals, represents instead a permanent, inescapable link to chemicals, as the new creation has a built-in tolerance to a specific herbicide. Hence, the chemical corporation gains twice: once, when they sell the biotechnology, and second, when it ensures thereby "permanent addiction" to its own patent herbicide. In contrast, the people and the environment, correspondingly lose twice: once because the proposed "safe" product ultimately is not, second, when other possibly safer, organic and sustainable choices, are preempted instead.

The October, 1991 issue of The Gene Exchange (Vol. 2 (3), lists 54 genetically engineered plants (USDA nos. 116 to 170), approved from February 5, 1991 to 
August 7, 1991 (four of these were still under review at that time). Nine of these exhibit "tolerance to herbicides" ranging from Glyphosate, chlorsulfuron, bromoxynil, glutosinate and 2, 4-D, either as their sole "engineered trait" or as one of a cluster of such traits. In most cases, the USDA grants permission while only "assuming" that approved tests have been conducted, and "confidential business information (is) withheld from the public during review" (The Gene Exchange, op. cit., p. 14). Attempts are made to regulate things in various locations. For instance, in 1989 "North Carolina enacted the first comprehensive state biotechnology law" (ibid, p. 4). Although it appeared to be a great step forward, and to provide for information to and input from the public, in essence its intent was "to protect and promote the industry" (p. 4).

Some of its problems were:

a) its ten-member review board only had one public interest representative;

b) public participation was "at the discretion of state regulators," and public hearings were permitted only when NCDA would determine that significant public interest and justification was present;

c) the Commissioner was the only one to determine if and when the public would be allowed to review CBI (confidential business information) (ibid, pp. 4-5).

Since not everyone is aware of the present-day role and issues of biotechnology, it seems to me that this brief presentation of the climate within which presentday "creators" work and some of the issues involved would not come amiss. Now, where animals are involved, the "new" species is once again often "new" in only one significant aspect. BGH (Bovine Growth Hormone, or BST, as it is sometimes known), is a hormone. Although scientists have not to this date been able "to fully determine how BGH works at the cellular level, they know that the hormone stimulated bone and muscle growth, metabolic rate and food intake, and milk production" $(G E$, p. 9). Monsanto, American Cyanamid, Eli Lilly and Upjohn are producing the hormone in the hope of selling it to farmers who would inject their cows for increased (and longer) milk productivity.

What are the differences between people working in the field of "monster" (as "unnatural" or "man-made" entities) creation today and in Dr. Frankenstein's time? The first and most significant difference is the relation between their respective work and their perceived "responsibility to their own species." Today's plant pathologist or other biotech specialist is motivated, prima facie at least, by the desire to "feed the hungry" by increasing productivity. Anecdotally, often the response elicited by questions from a concerned environmentalist about ecological safety is "do you people want us to allow millions to starve?" And clearly, prudential considerations are the easiest to voice in that setting, as concerns for the rights or the integrity of animals and plants would be dismissed out of hand.

Of course the implied dichotomy between sustainability and ecology does not exist, and I have addressed this question in detail elsewhere in regard to LDC's (Westra, Bowen and Behe, Journal of Agricultural Ethics, Sept. 1991). In essence the authors of Food 2000 say that all attempts to separate environmental concern from agricultural progress can only give rise to "invidious distinctions between environment and development:"

These views are based on a misunderstanding of the issues. If a country wishes to pay attention to the economic costs (and benefits) of agricultural production---and all countries do-it must deal with the environmental costs (Food 2000, 1987).

Hence, what is required is agricultural practices and regulations that are no longer "ecologically blind in their conception, funding and implementation." These must be given "ecological eyes" (Food 2000, 1987; cp. Westra, Bowen and Behe, 1991).

Nevertheless, even though ecological concern of this sort, let alone concern for animal ethics, is not viewed as a priority by biotech "creators," the human concern remains paramount: theirs is an anthropocentric position of responsibility toward the human species, not a stance based on selfishness. The conflict faced by the original Dr. Frankenstein no longer exists: rightly or wrongly, his latter-day counterparts are convinced that what they do represents "progress" and is "for the betterment of mankind." There appears to be no opposition between professional and personal fulfillment and the "duty to the species" in this context. Nor is the present-day Frankenstein a "creator" in the original sense: Dandekar and Zlotowski say "he is the scientist-technician 
bending dead matter to his will." But today's biotechnologists manipulate existing, live "matter;" they do not "create" ex nihilo. The "new" life form is only so in a partial sense: both virus or micro-organism and plant, for instance, were "life-forms" in their own right, before being joined.

Finally, there are great differences among those who accept Biblical and Christian beliefs. Although Dandekar and Zlotowski correctly cite Biblical passages from Genesis, there are those today who interpret Christian scriptures in a different vein. For instance, the Christian Farmers of Ontario and Alberta (Canada) publish a journal entitled Earthkeeping. These are primarily Dutch reformed or Mennonite farmers. Most run family operations, and economic considerations are as important to them as to any other farmer. Yet, one can find articles and features raising questions about the morality and godliness of interfering with the physical integrity of animals, even to increase production. For instance, the use of $\mathrm{BGH}$, discussed above, is rejected by these farmers precisely on Christian grounds, as interfering with the "integrity of creation," or God's plan for the world. Hence, a Christian position may entail respect for all that exists, as well as (or instead of) the arrogant attitude with which the authors identify Christian beliefs.

To sum up, the major differences between the original and latter day Frankenstein, centre on

a) the motivation of their research,

b) the way the product of the research is viewed, and

c) the very basis and format of such research.

Aside from these common features, other differences may be present as well.

Let us now turn to the proposed analogy: what are the similarities between the fictitious Dr. Frankenstein and the real ones? What is the lesson to be learned form the original work and the proposed analogy, if any?

\section{Dr. Frankenstein: The Breakdown of an Analogy.}

As noted in the two previous sections, Dr. Frankenstein is not like his present day counterpart in many respects. Nor is the variety of bioengineered species anything like the "creature." Finally, even the relation between creator and the created does not appear to carry the same overtones or to elicit the same successive emotions. What remains constant then and now? What is left is a cluster of general features,

a) the total lack of moral concern,

b) the way the scientific enterprise is viewed, and most important,

c) the presence of the same logical fallacy in their respective reasoning.

The error of perceiving scientific questions as "purely technical", rather than involving moral issues and values, persists today, as does the high and almost unassailable status of the "scientist" or "expert." Enough has been written on both problems by such well-known thinkers as Kristin Shrader-Frechette, Mark Sagoff, Helen Longino and others that there is no need to repeat their arguments here. As far as (c) is concerned, the logical confusion it indicates is still rampant today. Few acknowledge the vast gulf separating theory and practice, and thus they confuse the right to free thought and belief with that of practice; hence, the right of free scientific investigation with that of action or technological application.

The right to the latter, however, is not privileged: it must be limited, as all activity, by the right of others to safety and freedom from harm. Lately, a further dimension has been added to this obvious tenet. The definition of " moral patients" or the targets of such moral considerability is by no means as clearly defined as it might have been in Frankenstein's time. Hence, those who recommend caution and care are not improperly attempting to limit the soaring of the human (scientific) spirit: they are simply (minimally) recommending respect for others.

Aside from these general aspects of similarity, there are more problems with the proposed analogy, and even with the use made of it. For instance, it seems to me that the "creature's" plea for direct rather than indirect duties on the part of humans, the recognition of his creator's power to decide is confused with the acceptance of the latter's anthropocentrism. Dandekar and Zlotowski say, "Frankenstein's creature declares itself willing to accept the anthropocentric perspective" when he pleads for his own intrinsic value. But subsequently they suggest that anthropocentrism is transcended. "Frankenstein's creature... nevertheless demands that its maker directly recognize its needs." 
Dandekar and Zlotowski appear unsure, but this seems a clear case of demanding one's rights, rather than requesting compassionate stewardship.

Further, it seems difficult to compare the "destructive practices of industrial (or for that matter, agricultural) polluters who fill their own environment with carcinogens" to the relation between Frankenstein and the creature. The latter's concern is individualistic; the appeal to environmental concern, as well as that to Aldo Leopold and "biotic right," are holistic instead. No concern for a single animal "creature," or even species, is ever analogous to a holistic concern for the ecosystem which represents the life-support system on which individuals and groups depend. The two approaches are different in kind from one another.

"Stewardship," like "nonwanton" use, "the promotion of legitimate interests," and even "clemency" and "compassion" are all concepts based on anthropocentrism, inimical to the intrinsic value of nonhuman entities and lacking respect for their rights (if any) or their survival: they all remain expressions of speciesism. Finally, there is a basic disanalogy between even an intrinsic value/ individual rights based doctrine, and Aldo Leopold's "Land Ethic," or any other ecosystem-based approach. The latter supports the moral considerability of an ecosystem, an entity that is only "alive" in a specific way and that is neither "sentient" nor such that "it recognizes and defends its own interests."

Hence, Dandekar and Zlotowski are correct in arguing for the necessity to transcend current anthropocentric paradigms in the service of the interdependent community of life on earth. They are equally correct in perceiving technology as a real threat on several levels. They are, however, incorrect in proposing Dr. Frankenstein, his "creature" and their respective relation as a valid analogy to the present relation between biotechnologist and bioengineered species, or in thinking that the moral problems arising within the former might help in formulating answers for the latter.

\section{Conclusion}

Biotechnology poses moral problems at both the theoretical level and at the practical one. The theoretical problems need to be clearly worked out, in a timely manner, while economic interests continue to expand the use of biotechnologies without allowing the public any input in the decision to do so, or clearly understanding the moral and social implications and possible consequences. One is reminded of the nuclear industry and their rush to license facilities without any clear understanding of how safe storage of radwaste material might be effected. The Society for Ethics and Animals should be an excellent forum to design plans to deal with this issue, perhaps starting from the question raised by the Christian Farmers mentioned earlier: should we not respect the integrity of each creature? What separates justifiable paternalistic intervention (such as inoculations against disease or protection from parasites, both of which kill life-forms in an implicit hierarchical ranking), from unjustifiable intrusion? VanDeVeer's work on "interspecific justice" may provide a starting point for future discussion.

Nor is the problem only one of concepts, attitudes and worldviews; the urgent problem is one of establishing guidelines and rules to implement protection from harm. Biotechnologies have been heralded by their manufacturers as providing salvation from possible problems, yet they are far from problem free. Dr. Margaret Mellon, J.D. (Director, Biotechnology Regulations, World-wide Wildlife Federation), has listed no less than eight possible clusters of problems:

1) they may not be safely used in areas where living organisms (human and nonhuman) are malnourished or unhealthy;

2) the possible "combined impact of the rapid genetic improvement of the world's major commodity crops threatens to deprive millions in the Third World of their livelihoods," while advantaging multinationals and larger producers;

3) although these are presented "as ending the era of chemical agriculture," they will "shackle the world to herbicides for the foreseeable future" (as we saw in sec. 2);

4) the promised increased yields may, paradoxically, increase the misery of millions of poor farmers; and finally, and perhaps worst of all,

5) "biotechnology diverts all of us from the better path of sustainable agriculture." Dr. Mellon says:

The World Resources Institute...just released a study that concluded that if the costs of 
agriculture are fully accounted - that is, if the cost of water pollution and soil erosion were put into the equation--low input, alternative agriculture systems perform belter than conventional agriculture, and the former, rather than biolechnology is the path that will eventually feed people without destroying the environment (Mellon, 91).

On the question of health, three more problems arise:

6) biotechnology poses environmental risks: traits can be transferred to crops' "weedy relatives," especially in LDC's;

7) once genes are put into food crops for pesticides, they cannot be washed off and may pose risks to humans, as yet not fully comprehended (e.g. BT toxin);

8) risks exist from these technologies to wildlife, particularly fish.

In the face of such overwhelming problems, Dandekar and Zlotowski are to be commended for bringing the topic of bioengineering into the open. On the other hand, even at best, Dr. Frankenstein, as we have seen, raises questions of human attitudes to individual, nonhuman rights. The problems raised by today's biotechnologies instead are global and holistic and require urgent answers. I doubt that a consideration of Dr. Frankenstein's dilemma will suggest any new answers. Even the final suggestion, that it is Frankenstein's male chauvinism which dictates his adversarial, confrontational position toward naturewhile probably correct to some extent, receives a problematic answer in the paper's appeal to ecofeminism.

Time will not permit a lengthy analysis of this question, which I discuss elsewhere (for a short version of my position, see the latest APA Newsletter on Feminism and the Environment). Ecofeminism is essentially a form of feminism, hence a position seeking individual rights and aggregate, social recognition. From a policy-making perspective, this indicates that if a question of priorities arose, these would be sought before ecological concern, indicating again the possibility of conflict between the individual and the holistic stance. Dandekar and Zlotowski themselves suggest that holistic considerations are necessary to indicate solutions to the acute environmental challenges that face us. To that end, it seems to me, the analogy with Dr. Frankenstein and his creature does not really hold, and the hope for answers arising from it is not justified.

\section{Bibliography}

Barton, J.H., "Background Paper: Regulatory Arrangements for Developing Nations' Releases of Transgenic Organisms and Circulation Draft of Final Report of Biosafety Workshop of the Stockholm Environment Institute (SEI)": presented at the American Association for the Advancement of Science, 1991.

Engel, J. Ronald, and Joan Gibb Engel, Ethics of Environment and Development (Tuscon: The University of Arizona Press, 1990).

Food 2000: Global Policies for Sustainable Agriculture (New Jersey: Zed Books Ltd., 1987).

Hopper, W. David, "Role of Horticulture in the Economy of Developing Nations: a Global Overview," Hortsci 24 (6), 1989.

Mathews, J.T., World Resources 1986: A Report by the World Resources Institute and The International Institute for Environment and Development (New York, Basic Books, 1986).

Mellon, Margaret, "Agriculture Biotechnology in Latin America: an Environmental Perspective," for the XVI International Congress of the Latin American Studies Association, VA, April 6, 1991 . (Margaret Mellon, Ph.D., J.D., is Director, Biotechnology Regulations, National Wildlife Federation).

Pesek, J., Alternative Agriculture (Washington, DC: National Academy Press, 1989).

Science, Vol. 254, "Biological Immigrants Under Fire”, Dec. 6,1991, (1444-47).

Shrader-Frechette, K., Risk and Rationality (Berkeley: University of California Press, 1991).

Sheen, D. and P. Kretchmer, "Agriculture and Rural Development Strategy”, HortSci., 21, 1986.

The Gene Exchange, Vol.2 (3), 1991.

Westra, L., Bowen, K. and Behe, B., "Agricultural Practices, Ecology and Ethics in the Third World," in Journal of Agricultural and Environmental Ethics, Sept. 1991.

Westra, The Principle of Integrity: An Environmental Proposal for Ethics, forthcoming. 